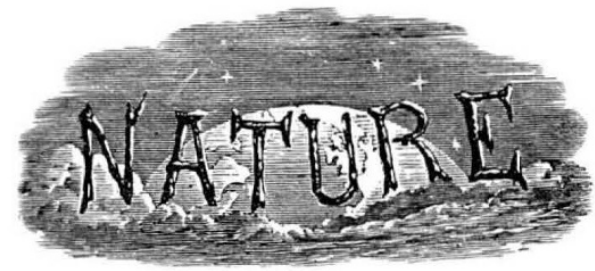

SATURDAY, DECEMBER 6, 1930.

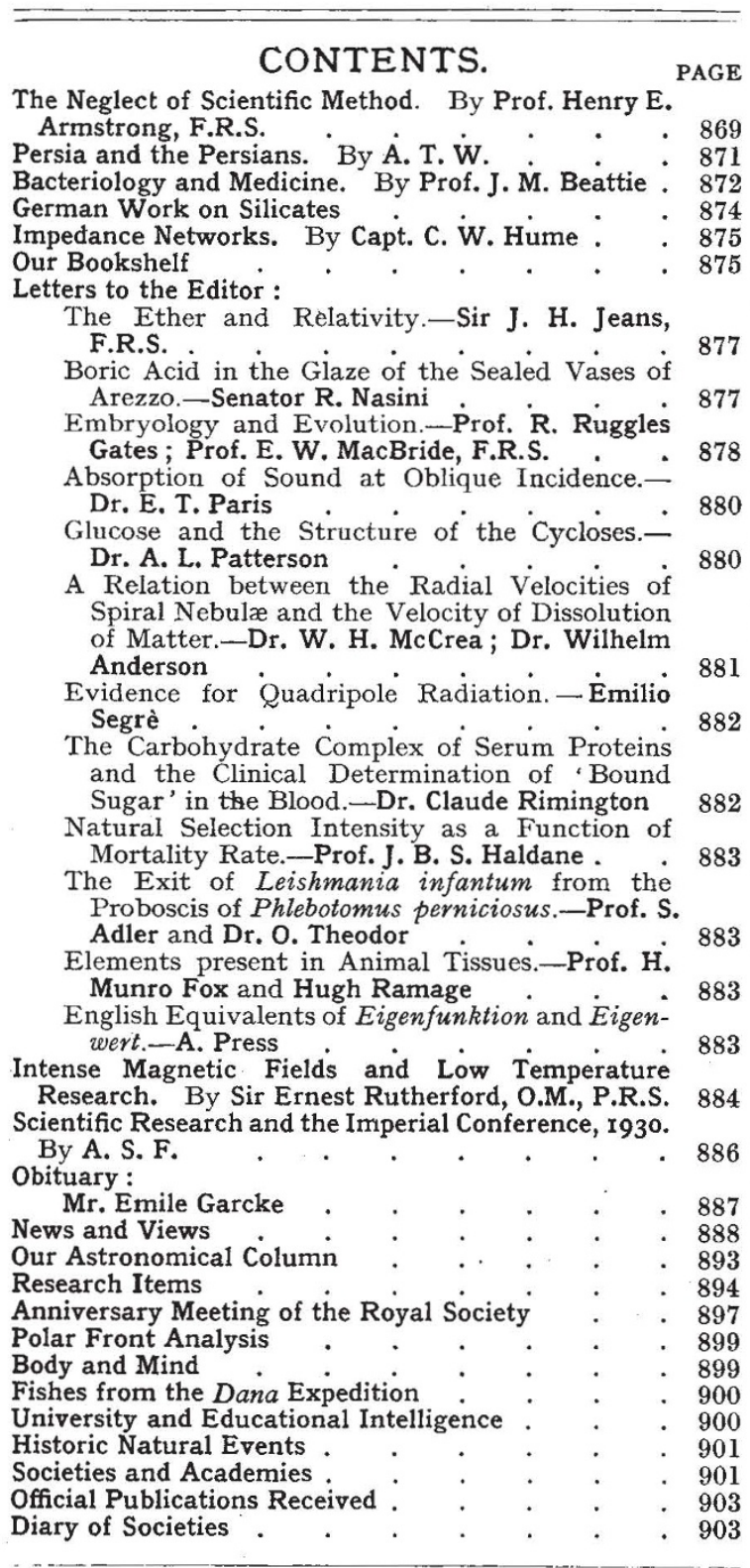

Editorial and Publishing Offices:

MACMILLAN \& CO., LTD.,

ST. MARTIN'S STREET, LONDON, W.C. 2.

Telephone Number: GERRARD 8830.

Telegraphic Address: PHUSIS, WESTRAND, LONDON.

No. 3188, VoL. 126]
The Neglect of Scientific Method.

THE address by Sir William Pope, at Gold1 smiths' Hall on Nov. 13, the sixth of the annual Norman Lockyer lectures instituted by the British Science Guild,* must be accounted one of the most weighty of recent scientific pronouncements, as well as most opportune, in its bearing upon two subjects of special interest at the moment - the extension of the Dyestuffs Act and the schoolleaving age. It is to be hoped that, without delay, the printed lecture may, in some way, be brought under the notice of every headmaster and of every member of Parliament; as the girls to-day are even more victimised than are the boys at school and college by the imposition of a burden of inconsequent, undigested learning, headmistresses might also be induced to understand the implications of the address.

Sir William Pope does well to lay stress upon the fact, that modern man is in no appreciable degree the intellectual superior of his forerunners in the far fringe of historic time: he differs from them only in having other weapons. As he truly says, the forms of intellectual expression we recognise as the arts and literature, even moral philosophy, were worked out thousands of years ago, to the utmost limit of the capacity of the human mind. No convulsive revolutionary change could affect our outlook, our powers and our achievements, except the discovery and exercise of some unsuspected faculty of our intelligence. Such a faculty is now to be recognised as operating in the background in the modern development of the natural sciences by experimental study, wherein we may see a most wonderful fulfilment of Shelley's far-seeing foresight:

A mighty Power, which is as darkness,

Is risen out of earth and from the sky

Is showered and, from within the air,

Bursts, like eclipse which had been gathered up, Into the pores of sunlight.

The Power is no longer "as darkness" but a sublime light. The intensive work which has been done in science, largely during the last fifty years, has launched us, says Sir William Pope, well beyond the shore of a new era in the world's history, an era which may be described as the scientific age. Unfortunately, the process is in no way understood even by the superior politician, let alone the public. The words science and scientific as yet have no properly defined meaning in the public mind ; even in scientific journals they

* "Science and Modern Industry." By Sir William J. Pope. Pp. 16. (London: British Science Guild, 1930.) is. 
are often inconsistently used and rarely with forethought. We have no right to confine the word science to any particular branch of knowledge; moreover, all exact and logical users of knowledge and experience are entitled to be spoken of as scientific. The modern advance, in all fields, is due to our considered application of knowledge and our constant verification of whatever conclusion we may draw : only the verified is science. Much that so passes at the moment is mere speculation. In days gone by, conclusions were based upon first principles, without verification.

The great Helmholtz tells us, in his biography, how the philosophers, in his early days, regarded the introduction of experimental verification as unnecessary ; in fact, as almost an insult to their dignity. Our use of the Latin word science, in place of knowledge, as if it meant something different and peculiar, is at the root of the difficulty: as a people, we cannot suffer Latin; much as we use it in our spoken language, we seem rarely to grasp the full meaning of Latin words. Until we study English, we never shall-unfortunately, this subject is still all but unknown in the schools; whatever stopped the way in the past, 'science' now crowds it out! Much of Sir William Pope's address is devoted to a criticism of the general literary ignorance of young people coming up to the university from the schools. He also complains bitterly of the neglect of modern languages. Being himself gifted with most remarkable linguistic ability, no one has greater right to speak upon the subject.

That a leading professor at a leading university should so speak out is a more than welcome sign that, at last, we are beginning to appreciate the danger of our position-that at last we see that the vicious circle in which youth is forced to revolve must in some way be broken and teaching made the free and considered practice of the greatest of all arts-an art nothing short of sacred. Research will soon be its own executioner, if we do not bring under effective consideration the methods of training used in school and university leading up to such work. What is now done is mainly by way of compensating for the absence of a proper educational foundation upon which a scientific superstructure may be built. The present situation is farcical. Trained at school and, say at Oxford, up to the end of his third year, to remain ignorant of method, suddenly the student is called upon to study ' the methods of research '-usually by working out an additional example after a well-known rule: in the main, he merely raises his value as an artificer. The art of logical inquiry and studyscientific method-should be inculcated from the cradle upwards: it is not to be learnt from the conventional ' research'.

This is really the meaning to be read into Sir William's address : and Brutus is an honourable man. He is a man who has shown supreme general business ability, having recently passed through the high City office of Prime Warden of the Goldsmiths' Company with great distinction. $\mathrm{He}$ is therefore a double first. His complaint is that most of the men in business and the politicians-I suppose he would say without exception-have no scientific training: they are empiricists, members of a class who have done in late years and are doing to-day, with alarming efficiency, everything possible to wreck our national fortunes. It is in the hands of such men that the fate of our dyestuff industry rests: theirs not to reason why, the decision is likely to be one taken without any intrusion of scientific method; the more as the industry is pre-eminently scientific, in origin and development.

In fact, our era is not yet to be spoken of as 'scientific', whatever the Norman Lockyer lecturer may assert. So few among us have any use for scientific method that the vast mass perish for want of such knowledge. Knowledge we have-a vast knowledge: only the knowledge how to use knowledge profitably is wanting among us. Our great present need is to appreciate the depth of our ignorance, especially in education.

Sir William Pope in and by his address sounds the trumpet call for action in the universities; it behoves the few who are alive to our educational peril to be up and doing, in remedy of his indictment. The headmasters will not move-they have not the courage nor any leader; the schools examining bodies will be opposed to all action; the public always leaves school to 'mother'. A colossal burden of responsibility rests upon the few at the universities who are aware of the straits into which education has drifted, through entire lack of scientific control, left as it has been in bureaucratic, unpractical hands. The universities, whatever may be said, are the prime source of all evil as well as of the little good in the prevailing chaos of teaching: they must cure themselves, in the first instance. Educationally they are unco-ordinated. We must exorcise the competitive lust that is within us, to the extent that we cease from treating education as if it were a branch of sport and our schools racing stables. In some way, we must take the money out of the examination purse and put 'morality' into its 
place. In some way, education must be made real and of general avail-not the entirely fortuitous, inhibitory process it now too often is.

So little scientific is our era, that the chief use we have made of our great knowledge has been to squander natural resources in a blind and selfish pursuit of wealth. Industry, to-day, is entirely inconsiderate of the future. We cannot continue at present rates. The solution of the nitrogen problem by Crookes has brought us nearer to destitution rather than saved us, as the blind worshippers of mechanical success assert it has, by hastening the rate of depletion of irreplaceable phosphatic stores. We can clearly foresee in phosphorus the limiting essential factor to the world's progress :

Ohne Phosphor kein gemixte Pickles

stands written upon the wall. If we have any regard for the future, without loss of time we must learn to submit ourselves to scientific control. Unless we overcome the demagogue, there will be no health in us.

Sir Norman Lockyer, I am sure, would indeed have been more than satisfied to hear an address delivered in his memory such as that just given under the auspices of the Guild he founded. Never has the existence of the Guild been so fully justified; still, it cannot rest content with talk, however eloquent. The red flag of revolt must now go forward; the time for mercy to the incompetent is over.

Henry E. Armstrong.

\section{Persia and the Persians.}

A History of Persia. By Brig.-General Sir Percy Sykes. Third edition with Supplementary Essays. Vol. 1. Pp. xxxix $+563+15$ plates. Vol. 2. Pp. $\mathrm{xx}+6 \mathrm{I} 6+16$ plates. (London : Mactmillan and Co., Ltd., 1930.) 2 vols., $42 s$. net.

$\mathrm{L}^{\circ}$ ORD CURZON'S classic work on Persia, published in 1892, went out-of-print a few years later, and was never reprinted. Sir Percy Sykes made his debut in Persia in the following year, and but for interludes in South Africa and Turkestan was, until December 1918, on duty in that country as a consular official, representing His Majesty's Government and the Government of India. $\mathrm{He}$ has travelled very extensively, and to good purpose : he has written four other books on various aspects of life and manners in Persia, and is unquestionably the leading authority in Britain on the matters dealt with in the present work. That he should have found time, in the midst of his travels and official labours, to compile this history (the first edition was published in 1915) is a tribute to his versatility and to his pertinacious industry, for to write a standard historical work in a consulate in a remote provincial town on the borders of Central Asia is a task at which few men would persevere. That a third edition should be called for within fifteen years is a tribute to the widespread interest displayed by the Englishspeaking world in Oriental history.

"Official duty", said Lord Rosebery in 1898, " is only a very small part of public duty, and public work is by no means incompatible with other professions and other callings." The great historians of the East in the English language have with few exceptions been soldiers and administrators, who have been at pains to follow the precept of Habakkuk and to read as they ran. Sir Percy Sykes is the worthy successor in the field of Middle Eastern history of such men as Malcolm, Morier, Rawlinson, and Curzon.

The history of Persia is of unique importance to the student of past times, for, thanks to the discoveries of the last century, it constitutes a longer and more continuous record than that of any other country or nation. A few salient facts, as disclosed by the work under review, of special interest to readers of NATuRE, relating to ethnography and to the Persian people and their contributions to the progress of the human race, are worth mentioning.

In no eastern country is 'national' sentiment stronger: yet in no country has there been a greater admixture of extraneous elements. Persia has in the last two thousand years been overrun repeatedly by foreign invaders-by Arabs in the seventh century, by Mongols in the thirteenth, by Turks in the seventeenth, by Afghans in the tenth, and Russians in the nineteenth; at least six different racial strains are apparent amongst the population to-day, and as many languages are currently spoken, namely, Arabic in the southwest, Baluch (Brahui) in the south-east, Kurdish in the west, Turkish almost everywhere except in the centre, to which must be added the Tajik of the Caspian provinces, and Luri--which has strong affinities to the ancient Pehlevi tongue-in the south-west. Yet the Persian kingdom has had a continuous and unbroken existence since the dawn of history, and has extended at different times to Cairo and Delhi, to Samarkand and to the Hijaz.

The extensive conquests made by the armies of successive rulers entailed further great admixture of blood, for the Persian soldiery were wont to 